\section{KEY POINTS}

- There is a high ratio of nonperforming loans (NPL) to total loans in Bangladesh.

- NPLs imply foregone interest earnings for banks and often involve loss of the principal amount of loans.

- NPLs impair banks' balance sheets and restrict their capacity to lend, hindering investment and growth.

- Financial institutions need to strengthen lending discipline and streamline the recovery process to ensure that NPLs do not pile up.

- A revised bankruptcy act should set timebound procedures to expedite the resolution of cases for settlement.

- Fair pricing of collaterals through competent accounting firms with international best practices can mitigate loan default risks.

- The number of stateowned commercial banks can be reduced through consolidation, merger, or divestment.

- Setting up a public asset management company could be considered to expedite the NPL resolution process.

ISBN 978-92-9261-852-0 (print)

ISBN 978-92-9261-853-7 (electronic)

ISSN 2071-7202 (print)

ISSN 2218-2675 (electronic)

Publication Stock No. BRF190507-2

DOI: http://dx.doi.org/10.22617/BRF190507-2

\title{
Managing Nonperforming Loans in Bangladesh
}

\author{
Barun Kumar Dey \\ Economics Officer \\ South Asia Department \\ Asian Development Bank
}

\section{THE BANKING SECTOR IN BANGLADESH}

The banking sector plays a critical role in the economy, mobilizing savings and channeling the savings for productive investment. The better it does so, the better the economy will perform in the long-run through more productive economic activities and reduced financial risk. The role is even more pronounced in a developing country like Bangladesh, where the banks are the major source of long-term finance in the absence of a mature capital market.

A sound banking system ensures effective use of resources, facilitating efficient allocation. Access to capital by individuals, firms, and projects is critical, among others, for undertaking different social and physical infrastructure projects, creating jobs, and increasing productivity. Banking sector development is an essential condition for economic development because of its vital function of promoting capital formation, savings and investments, as well as development in agriculture, industry and trade, and services.

The banking sector in Bangladesh experienced challenging times, particularly in the immediate aftermath of the country's independence. In the early 1970s, authorities nationalized commercial banks, except for a few foreign commercial banks, to channel the prevailing low savings through the formal sector to support economic activities. This was rational as economic activities were mainly driven by the public sector players. Bangladesh Bank, the central bank, initially had direct control of both lending and deposit rates, and much of the lending went to state-owned enterprises.

In the early 1980s, the government undertook banking sector reforms, including allowing private sector banks to operate to create competition in the banking system. Two major state-owned commercial banks (SCBs) were privatized in June 1983. The government also recapitalized banks, introduced new loan classification systems, and made interest rates more flexible to strengthen money and capital markets.

Subsequently, more foreign commercial banks (FCBs) were allowed in and many private commercial banks (PCBs) were set up. As of December 2018, there were 57 commercial 
banks with 10,286 branches. ${ }^{1}$ The present banking sector comprises four categories of banks-6 SCBs, 2 state-owned development financial institutions (DFIs), 40 domestic PCBs, and 9 FCBs.

The banking sector's total assets stood at Tk14.6 trillion ( $\$ 173.7$ billion at the end of 2018) or 65\% of the country's gross domestic product as of December 2018 (Table 1). The market share of the SCBs that once dominated in the banking system has been shrinking over time while those of PCBs and FCBs have been increasing, reflecting enhanced competition in the banking sector. Notably, the assets structure continued to be dominated by loans and advances, estimated to be $62.5 \%$ of total assets. Such high concentration of loans and advances heightens the vulnerability of assets to credit risk. The banking sector's net profit (net income after provision and tax) steadily decreased from Tk83.3 billion in fiscal year 2010 (FY2010) to Tk44.7 billion in FY2012 partly due to additional loan loss provision requirements for the stricter regulation adopted by the Bangladesh Bank. Although thereafter net profit increased to Tk95.1 billion by FY2017 due to the drop in provision requirements resulting from extensive rescheduling facilities, it further declined considerably to Tk40.4 billion in FY2018 because of the higher provision requirement. Following the trend in net profit, the banking sector's return on asset also decreased to $0.3 \%$ in 2018 from $1.8 \%$ in 2010 , while the return on equity decreased to $3.9 \%$ from $21.0 \%$.

To strengthen the capital base of banks and promote a more resilient banking system, the Basel III regulation was introduced in January 2015 for adoption in phases; the full implementation of capital ratios took place in January 2019. At present, scheduled banks ${ }^{2}$ in Bangladesh need to maintain Tk4 billion as minimum capital or $10.0 \%$ ratio of capital to risk weighted assets, whichever is higher. In addition, a capital conservation buffer of $2.5 \%$ of the total risk weighted assets will be required to maintain in the form of common equity Tier $1 .{ }^{3}$ Despite these measures, the banking sector faces several issues such as low profitability, poor governance, rising capital shortfalls, lack of operational efficiency, low levels of automation, insufficient credit monitoring and internal risks management, lack of effective legal framework, and high levels of NPLs, especially in the SCBs and DFls although their market share is small.

\section{NONPERFORMING LOANS IN BANGLADESH}

There is no single internationally accepted definition of NPL. The International Monetary Fund (IMF) indicates that a loan is nonperforming when payments of interest and/or principal are past due by 90 days or more; or interest payments equal to 90 days or more have been capitalized, refinanced, or delayed by agreement; or payments are less than 90 days overdue, but there are other good reasons - such as a debtor filing for bankruptcyto doubt that payments will be made in full. ${ }^{4}$ NPLs in Bangladesh are classified as substandard, doubtful, and bad or loss, which are calculated based on uniform criteria. A loan is substandard if it is overdue for 3 months or more but less than 9 months, doubtful if overdue for 9 months or more but less than 12 months, and bad or a loss if it is overdue for 12 months or more. ${ }^{5}$

The size of NPLs in Bangladesh is much higher than in other countries in Asia and the Pacific. From its independence in 1971 until 1999, there was a steady rise in the share of NPLs in Bangladesh, with the gross NPL ratio to total loans in the banking system peaking at 41.1\% in 1999. NPLs have increased for all types of banks. The SCBs and DFls recorded the highest NPL ratios, as they granted loans on weak appraisal, and under directed lending programs, especially during the 1970s and 1980s. After loan disbursement, the banks' follow up on repayments was not strong, and such directed lending programs have led to a massive build-up of poor-quality loans, resulting in continued heavy losses. Banks were also reluctant in writing off the long-lasting

\section{Table 1: Banking System Structure in Bangladesh, December 2018}

\begin{tabular}{l|c|c|r|r|r|r}
\hline Bank Types & $\begin{array}{c}\text { Number of } \\
\text { Banks }\end{array}$ & $\begin{array}{c}\text { Number of } \\
\text { Branches }\end{array}$ & $\begin{array}{c}\text { Total } \\
\text { Assets }\end{array}$ & $\begin{array}{c}\text { Share of Assets } \\
(\%)\end{array}$ & $\begin{array}{c}\text { Deposits } \\
\text { Share of Deposits } \\
(\%)\end{array}$ \\
\hline SCBs & 6 & 3,746 & $3,732.2$ & 25.6 & $2,868.4$ \\
\hline DFls & 2 & 1,412 & 324.0 & 2.2 & 286.0 \\
\hline PCBs & 40 & 5,060 & $9,769.7$ & 67.0 & $7,127.2$ \\
\hline FCBs & 9 & 68 & 747.1 & 5.1 & 517.1 \\
\hline Total & 57 & 10,286 & $14,572.9$ & 100.0 & $10,798.7$ & 4.8 \\
\hline
\end{tabular}

$\mathrm{DFI}=$ development financial institution, $\mathrm{FCB}$ = foreign commercial bank, $\mathrm{PCB}$ = private commercial bank, $\mathrm{SCB}=$ state-owned commercial bank.

Source: Bangladesh Bank.

\footnotetext{
Data collected from Bangladesh Bank via e-mail correspondence.

Banks that operate under full control and supervision of Bangladesh Bank, empowered through Bangladesh Bank Order, 1972 and Bank Company Act, 1991.

Bangladesh Bank. Regulators of the Financial System. https://www.bb.org.bd/fnansys/regulator.php.

4 IMF. 2005. The Treatment of Nonperforming Loans (BOPCOM-05/29) - Eighteenth Meeting of the IMF Committee on Balance of Payment Statistics. Washington D.C. June 27-July 1. https://www.imf.org/external/pubs/ft/bop/2005/05-29.pdf.

5 The central bank revised the loan classification rules effective 30 June 2019. Bangladesh Bank. 2019. Banking Regulation and Policy Department Circular No. 03. 21 April.
} 
bad loans mainly due to below standard underlying collateral and fear of probable legal complications. This also contributed to the increase of NPLs in the asset portfolio of these banks.

However, NPL recoveries witnessed significant improvements after 1999, as the NPL ratio steadily decreased to $6.1 \%$ in 2011 due to written-off loans, provisioning, and a sharp decline in new bad debt. Aside from stronger regulation, greater legal powers of the banks to recover problem loans through the money loan courts and better screening of new loans by the Credit Information Bureau also contributed. ${ }^{6}$ But NPLs further rebounded to $10.0 \%$ in 2012, and with some fluctuations, it again rose steadily, from $8.8 \%$ in 2015 to 10.3\% in 2018 (Figure 1). The SCBs and DFIs continue to record high levels of NPLs due to the implementation of new and tighter loan classification and provisioning standard, and approval of large loans without much scrutiny, among others.

Cross-country comparison of NPLs is difficult, as there is no universal definition of an NPL and accounting rules vary in different countries. But the 90-day period is widely used by countries to determine a loan to be nonperforming. Cross-country comparison with some countries in Asia and the Pacific shows that the NPL ratio to total loans in 2017 was highest in India (10.0\%), followed by Bangladesh (9.3\%), Thailand (3.1\%), Indonesia (2.6\%), Viet Nam (2.3\%), Sri Lanka (2.5\%), the People's Republic of China (1.7\%), and Malaysia (1.5\%) (Figure 2).

The NPL ratio for banks in India steadily increased from $2.3 \%$ in 2008 to $10.0 \%$ in 2017, while the ratio is low in the People's Republic of China (PRC), around $1.7 \%$ of total loans from $2.4 \%$. The NPL ratio in Sri Lanka steadily declined to 2.5\% in 2017 from 5.6\% in 2013. The NPL ratio showed a decreasing trend in Thailand, down to $2.3 \%$ until 2013 from $5.6 \%$ in 2008, but increased to $3.1 \%$ by 2017 . In Malaysia, the NPL ratio fell gradually from $4.8 \%$ in 2008 to $1.5 \%$ in 2017 . The NPL ratio in Viet Nam increased from 2.2\% in 2008 to 3.4\% in 2012, and thereafter declined and remained stable at 2.3\% in 2015-2017. NPLs that engulfed the financial system in the Republic of Korea during the Asian financial crisis has recovered significantly and remained stable at the range of $0.5 \%-0.6 \%$.

Any irregularities in credit management can accumulate NPLs in the banking system. The presence of an alarming amount of NPLs leads to undesirable effects for banks, including the following:

(i) NPLs limit new lending capacity. Unless money lent out is recovered in a timely manner, it will not be available to make fresh lending. When the problem becomes prevalent in the financial sector, the banking system becomes unable to provide credit, including working capital, to the economy's productive segments. This results in an economic slowdown.

(ii) Rising levels of NPLs require banks to raise provisions against probable loan losses and carry out internal consolidation to

\section{Figure 1: Gross Ratios of Nonperforming Loans to Total Loans, by Type of Bank}

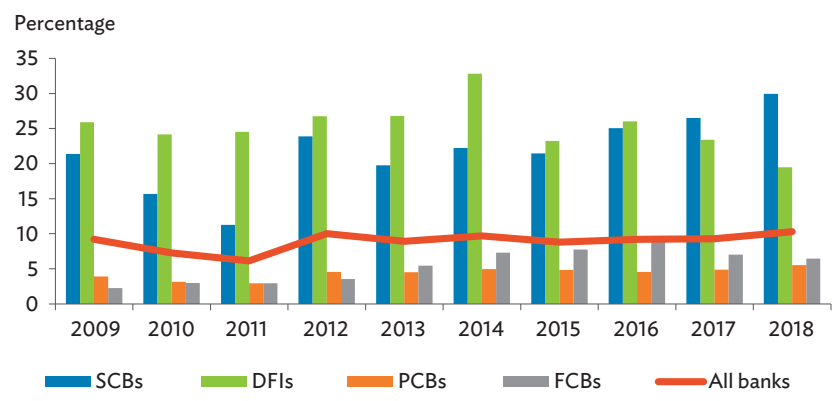

$\mathrm{DFI}=$ development financial institution, $\mathrm{FCB}=$ foreign commercial bank, $\mathrm{PCB}=$ private commercial bank, $\mathrm{SCB}=$ state-owned commercial bank. Source: Bangladesh Bank, Annual Reports 2016-2017 and 2017-2018. Figure 2: Gross Ratios of Nonperforming Loans
to Total Loans in Asia

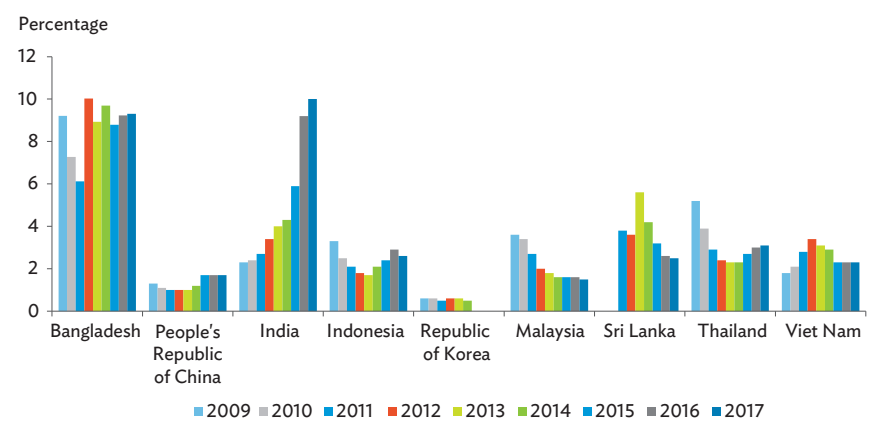

Source: World Bank. World Development Indicators database. https:// databank.worldbank.org/source/world-development-indicators (accessed 15 October 2018); and Bangladesh Bank. 2019. Annual Report 2017-2018. January. https://www.bb.org.bd/pub/annual/anreport/ar1718/index1718.php.

improve asset quality, including writing-off loans. The resulting decline in credit disbursement leads to a lower return on assets and return on equity, affecting bank solvency and liquidity.

(iii) The profitability of a bank can determine the bank manager's risk-taking behavior. Banks with high NPLs cannot take risk due to lower profits. Funding costs also rise, as counterparties seek to cover the risks of lending to weakened banks.

Overall, the high NPL ratio diminishes the overall credit quality of the banking sector in Bangladesh. Banks act as custodians of the assets of the general public, and influence and facilitate economic activities, such as resource mobilization both in the public

6 S. A. H. Shah. 2008. Bangladesh Financial Sector an Agenda for Further Reforms. Asian Development Bank. https://www.adb.org/sites/default/files/ publication/27528/financial-sector-ban.pdf. 
and private sectors, production and distribution, and poverty reduction. It is thus critical to implement adequate measures to effectively address the flow problem of bad loans.

\section{RESOLUTION STRATEGIES FOR NONPERFORMING LOANS IN BANGLADESH}

The Government of Bangladesh adopted several measures to ensure better policy framework and manage NPLs. The National Commission on Money Exchange and Credit was formed in 1986, which suggested administrative and judicial measures for solving problem loans of SCBs and DFIs.? The Financial Sector Reform Project was started in 1990 to enact different laws and regulations to expedite settlement processes. In 1996, the Banking Reform Committee was established, which suggested framing a concrete loan recovery policy for SCBs and examined the viability of forming an asset management company (AMC) for settling NPLs. The Structural Adjustment Performance Review Initiative in 2000 concentrated on better loan screening and monitoring standards of individual banks while the Credit Risk Grading Manual was prepared in 2005 to make the Credit Risk Grading system mandatory for analyzing credit risk. In 2007, the focus was on corporatizing SCBs and increasing the minimum capital adequacy ratio from 9 to $10 .{ }^{8}$ In 2012, measures were adopted for tightening loan classification and establishing provisions that are more in line with international practices. Key provisions in the Bank Companies Act were amended in 2013 to provide the Bangladesh Bank full regulatory and supervisory control over the SCBs. In 2014, the financial reporting of bank branches was automated, and in 2015, several measures were implemented, including placing observers in the board of banks with worsening internal governance, restructuring of large loans, and signing by SCBs of annual performance agreements with the government (Figure 3).

Since early 2019, the government has been devising several reform measures to enforce greater discipline in the financial sector. As part of this, the government is reviewing several acts, laws, regulations, and guidelines for amendments, where necessary. These include, among others, the Bangladesh Bank Order, 1972; Bank Company Act, 1991; Bankruptcy Act, 1997; Money Loan Court Act, 2003; and regulations on mergers and acquisitions. The government is also planning to set up special audit for banks to investigate anomalies in the sector. In the meantime, the Bangladesh Bank introduced new guidelines on an internal credit risk rating system for banks effective 1 July 2019 and eased the loan classification and provisioning rules extending the loan repayment period by 3 months effective 30 June 2019. Other recommendations by a six-member committee formed in early 2019 comprising of the Ministry of Finance and Bangladesh Bank, included forming of an AMC, creation of secondary market for NPLs, setting up a separate data warehouse for NPLs under the existing facilities of the Credit Information Bureau of the Bangladesh Bank, and a tax rebate facility for traders of the default loans that remain under consideration. The Secured Transaction (Moveable Assets) Act is also under processing, scheduled to be passed by the Parliament the next year, allowing borrowers to also use their movable assets as collateral with banks.

\section{LEARNING FROM EXPERIENCES OF OTHER COUNTRIES}

Despite adopting the above measures, Bangladesh had limited success and NPLs remain high. It is thus important to look at other countries' measures in dealing with excessive NPLs. To reduce NPLs to acceptable levels, creative regulatory solutions and well-designed risk mitigation techniques have been utilized in several countries in Asia and Europe.

Following the 1997 financial crisis, many banks and nonbank financial institutions in the Republic of Korea had piled up huge amounts of NPLs in their balance sheets, and the losses originating from the accumulation of bad loans led them close to bankruptcy, threatened the stability of its financial system, and posed systemic risks to the entire economy. To address the situation, the Government of the Republic of Korea went on a complete overhaul of the financial sector within a short time. ${ }^{9}$ It cancelled licenses and suspended operations of nonviable lending institutions that failed to meet the minimum capital adequacy standard, cleaned up balance sheets of healthier ones, created a relatively small number of large banks through mergers, and let restructured banks take charge of corporate restructuring with allocation of public resources. The Korea Asset Management Corporation (KAMCO) purchased NPLs at a considerable discount and sold it at impressive prices for profit. The insolvent banks acquired by the healthier banks also received capital injected through public bonds issued by the Korea Deposit Insurance Corporation and guaranteed by the government on interest costs. Because of this aggressive reform, commercial banks had become more transparent and healthier than before, and both foreign and local investors' confidence has largely been restored. As a result, the NPL ratio dropped. The Republic of Korea's comparatively mature legal framework and further reforms of its bankruptcy law, and securitization contributed to KAMCO's success.

The 1997 Asian financial crisis seriously affected the banking and financial system of Malaysia and caused sharp currency depreciation

7 S. Parven. 2011. Nonperforming Loans of Commercial Banks in Bangladesh. Munich Personal RePEc Archive Paper No. 65248. Bangladesh Institute of Bank Management. 27 November. https://mpra.ub.uni-muenchen.de/65248/9/MPRA_paper_65248.pdf.

8 IMF. 2018. Bangladesh: Selected Issues. IMF Country Report No. 18/159. June. https://www.imf.org/en/Publications/CR/Issues/2018/06/08/BangladeshSelected-Issues-45960.

9 Y. C. Park. 1999. The Banking Reform in Korea: Issues and Challenges. In Bank for International Settlements. [BIS Papers No. 7: eStrengthening The Banking System In China: Issues And Experience]. October. pp. 263-343. https://www.bis.org/publ/plcy07r.pdf. 


\begin{tabular}{|c|c|c|c|c|}
\hline \multicolumn{5}{|c|}{ Figure 3: Measures Adopted to Address Nonperforming Loans in Bangladesh } \\
\hline 1986 & 1990 & 1996 & 2000 & 2005 \\
\hline $\begin{array}{l}\text { National Commission on Money } \\
\text { Exchange and Credit: } \\
\text { - Setting of recovery targets for } \\
\text { SCBs and DFIs } \\
\text { - Prohibiting defaulters from } \\
\text { access to further credit } \\
\text { - Linking loan recovery measures } \\
\text { with the central bank }\end{array}$ & $\begin{array}{l}\text { Financial Sector Reform Project: } \\
\text { - Enacting new laws, regulations, } \\
\text { and instruments (such as, } \\
\text { Financial Loan Court Act, } 1990 \\
\text { and Bankruptcy Act, 1997) } \\
\text { - Fixing collection targets and } \\
\text { resolution of legal cases for the } \\
100 \text { largest defaulters } \\
\text { - Publishing list of } 100 \text { largest } \\
\text { defaulters in different media }\end{array}$ & $\begin{array}{l}\text { Banking Reform Committee: } \\
\text { - Formulating recovery cells and } \\
\text { camps in SCBs } \\
\text { - Introduction of incentives to } \\
\text { bank officials for recovery }\end{array}$ & $\begin{array}{l}\text { Structural Adjustment Performance } \\
\text { Review Initiative: } \\
\text { - Improving central bank's supervision } \\
\text { and regulation } \\
\text { - Enacting the Money Loan Court Act } \\
2003 \text { and the Bank Company } \\
\text { (Amendment) Act } 2003 \text { for quick } \\
\text { settlement of filed cases } \\
\text { - Central bank's instructions to banks } \\
\text { to maintain } 9 \% \text { ratio of capital } \\
\text { adequacy to risk weighted assets, } \\
\text { with core capital at least } 4.5 \% \\
\text { - Making provision to appoint } \\
\text { two directors from the depositors } \\
\text { in bank board }\end{array}$ & $\begin{array}{l}\text { Credit Risk Grading (CRG) } \\
\text { Manual: } \\
\text { - Making CRG system } \\
\text { mandatory from } 2006 \text { to } \\
\text { prevent fresh NPLs }\end{array}$ \\
\hline 2007 & 2012 & 2013 & 2014 & 2015 \\
\hline$\checkmark$ & & & $\downarrow$ & \\
\hline $\begin{array}{l}\text { - Corporatizing SCBs } \\
\text { - Transfer of regulatory authority } \\
\text { of SCBs from the Ministry of } \\
\text { Finance to the Bangladesh Bank } \\
\text { - Raising minimum capital } \\
\text { adequacy ratio from } 9 \text { to } 10\end{array}$ & $\begin{array}{l}\text { Revision of loan classification } \\
\text { and provisioning: } \\
\text { - Tightening loan classification } \\
\text { to bring it more in line with } \\
\text { international practices } \\
\text { - Tightening of definition and } \\
\text { delinquency periods for fixed } \\
\text { term loans }\end{array}$ & $\begin{array}{l}\text { - Amending the Bank Company } \\
\text { Act, giving Bangladesh Bank } \\
\text { authority to remove the } \\
\text { Managing Director of the SCBs } \\
\text { - Special diagnostic examination } \\
\text { of SCBs by Bangladesh Bank } \\
\text { - Signing by SCBs revised MoU } \\
\text { with Bangladesh Bank with } \\
\text { quantitative targets, including } \\
\text { reduction of NPLs, limits on the } \\
\text { growth of their lending portfolio, } \\
\text { and recovery from the largest } \\
\text { defaulters }\end{array}$ & $\begin{array}{l}\text { - Automation of bank branches } \\
\text { by end-2016 in financial } \\
\text { reporting }\end{array}$ & $\begin{array}{l}\text { - Placing observers in the board } \\
\text { of banks with worsening } \\
\text { internal governance } \\
\text { - Restructuring of large loans } \\
\text { above Tk5 billion } \\
\text { - Signing by SCBs annual } \\
\text { performance agreement with } \\
\text { the Ministry of Finance to } \\
\text { reinforce good practices }\end{array}$ \\
\hline \multicolumn{5}{|l|}{$\underset{\downarrow}{2019}$} \\
\hline \multicolumn{5}{|c|}{$\begin{array}{l}\text { Ongoing reform measures: } \\
\text { - If necessary, amendments to the Bangladesh Bank Order, 1972; Bank Company Act, 1991; Bankruptcy Act, 1997; Money Loan Court Act, 2003; Bank Nationalization Ordinance, 1972; } \\
\text { Financial Institution Act, 1993; Bankers' Book Evidence Act, 1891; Cooperative Societies Law, 2001; Negotiable Instrument Act, 1881; and regulations on mergers and acquisitions } \\
\text { Placing a special audit for banks to probe irregularities in the sector } \\
\text { - Launching a new guideline on credit risk management effective } 1 \text { July } 2019 \\
\text { Recommendations of forming of an AMC, creation of secondary market for NPLs, setting up a separate data warehouse for NPLs under the existing facilities of the Credit Information } \\
\text { Bureau of the Bangladesh Bank, and tax rebate facility for traders of the default loans } \\
\text { - Easing loan classification and provisioning rules effective } 30 \text { June } 2019\end{array}$} \\
\hline \multicolumn{5}{|c|}{$\begin{array}{l}\mathrm{AMC}=\text { asset management company, } \mathrm{DFI}=\text { development financial institution, } \mathrm{FCB}=\text { foreign commercial bank, } \mathrm{MOU}=\text { memorandum of understanding, } \mathrm{NP} \\
=\text { nonperforming loan, } \mathrm{PCB}=\text { private commercial bank, } \mathrm{SCB}=\text { state-owned commercial bank. }\end{array}$} \\
\hline \multicolumn{5}{|c|}{$\begin{array}{l}\text { Sources: S. Parven. 2011. Nonperforming Loans of Commercial Banks in Bangladesh. Munich Personal RePEc Archive Paper No. 65248. Bangladesh Institute } \\
\text { of Bank Management. } 27 \text { November. https://mpra.ub.uni-muenchen.de/65248/9/MPRA_paper_65248.pdf; IMF. 2018. Bangladesh: Selected Issues. IMF } \\
\text { Country Report No. 18/159. June. https://www.imf.org/en/Publications/CR/Issues/2018/06/08/Bangladesh-Selected-Issues-45960; and Bangladesh Bank. } \\
\text { 2019. Annual Report 2017-2018. January. https://www.bb.org.bd/pub/annual/anreport/ar1718/index1718.php. }\end{array}$} \\
\hline
\end{tabular}

as capital outflows accelerated; interest rates rose, hastening a recession in the real economy. Consequently, consumer and local companies faced difficulties in loans servicing, causing a sharp increase in the incidence of NPLs. ${ }^{10}$ To address these problems, measures were taken to restore confidence: the government guaranteed depositors' funds and decided that troubled institutions will not be closed. Three new state-run agencies were established in 1998: (i) Danamodal, a subsidiary of the central bank to recapitalize, restructure, and monitor performance of insolvent financial institutions; (ii) the Corporate Debt Restructuring Committee, a committee to restructure corporate debts by making a forum for lenders and borrowers; and (iii) Danaharta, an AMC to buy up, manage, restructure, or dispose of NPLs and assets attached as collateral, and to maximize the recovery value of the acquired assets. Due to the operations of these agencies, the NPL ratio came down to the level far below the market expectations. In recent practice of risk management, banks can dispose or sell their NPLs to nonbanking institutions as per the requirements of the guidelines under the Banking and Financial Institutions Act 1989, without affecting any debt restructuring agreements. ${ }^{11}$

To address NPLs and stabilize the finance sector, the Government of Thailand began guaranteeing deposits following the financial crisis. This urgent step was the basis for the next plans for addressing the cumulating NPLs through recapitalization of

10 M. Khor. 2005. The Malaysian Experience in Financial-Economic Crisis Management an Alternative to the IMF-Style Approach. TWN Global Economy Series 6. http://www.twn.my/title2/ge/ge06.pdf.

11 Bank Negara Malaysia. 2012. Sale of Non-Performing Loans by Malaysian Banks. 20 June. http://www.bnm.gov.my/index.php?ch=en_press\&pg=en_ press\&ac $=80 \&$ lang $=$ en. 
financial institutions and bad-debt resolution mechanisms. The government shut down bankrupt financial institutions and considered them for merger with others to sharply reduce the number of financial institutions. Another step the government took was encouraging foreign banks to actively participate in the financial sector to promote technological upgrading and allowed them to buy some major stakes of local banks to increase portfolio holdings in the sector. Foreign institutions had thus gained a notable market share in the financial sector. ${ }^{12}$ To restructure NPLs, two state-run agencies were constituted: the Thai Asset Management Corporation (TAMC), established in 2001 and funded by the financial institutions development fund, was allowed legal power to singly change loan terms, conduct debt-for-equity swaps, foreclose on debtor's assets, and reorganize assets; and the Corporate Debt Restructuring Advisory Committee, a committee that focuses on out-of-court work-out, which followed a more conventional approach of encouraging private negotiations between lenders and borrowers, and successfully restructured cases, though moved slower than the TAMC. ${ }^{13}$ The TAMC's recovery rate was much higher, as a profitsharing scheme further helped it maximize the recovery value of the NPLs. Besides, the government reformed its insolvency laws to sufficiently expunge the amount of NPLs.

The PRC's NPL issue did not stem from the Asian financial crisis and was rather a result of continued losses at state-owned enterprises and the absence of a commercial credit culture at major financial institutions. To deal with the NPLs and improve the operational performance of banks, in general, the PRC initiated a set of reform measures, including implementing a new accounting system, strengthening financial supervision and regulation, and recapitalizing the SCBs. In 1999, the government established four state-owned AMCs to purchase NPLs from the big four commercial banks in the PRC. Since 2001, foreign investors can also purchase NPLs in bulk from the AMCs through a competitive process. ${ }^{14}$ Also, certain qualifying foreign institutional investors can purchase NPL assetbacked securities in the PRC bond markets. Although the PRC largely followed KAMCO's model-applying a variety of NPL resolution methods, including debt-for-equity swap, restructuring, liquidation, direct sales to investors, and securitization-both the speed of resolution and recovery of the AMCs in the PRC lagged behind KAMCO and TAMC. This was primarily due to a lower asset quality, weak legal framework, transfer of NPL to AMC at book value, and poor governance and transparency at the AMCs. Consequently, the government undertook other proactive measures such as reforming legal framework, rationalizing NPL transfer pricing to AMCs, and restoring corporate cultures at AMCs. In a recent move toward penalizing the defaulters, the PRC imposed restrictions against defaulters (the Supreme People's Court blacklisted 6.73 million bank defaulters), keeping them from traveling by plane and high-speed train, applying for loans and credit cards, or getting promoted. ${ }^{15}$

The NPL problem in Japan is primarily the result of the bursting of asset price bubbles during late 1980s to early 1990s, with stock and land prices peaking in December 1989 and March 1991. Bank loans were overextended, particularly in property-related businesses such as real estate, construction, and nonbank financial services, with most of the loans collateralizing by land whose values declined after the burst, and cash flows were insufficient to repay the loans and hence turned into nonperforming. The economic slowdown and price deflation in the 1990s also led to the rise in NPLs, especially in the late 1990s and the early 2000s. Following the Asian financial crisis in 1997-1998, the government developed a comprehensive bank resolution framework, involving measures such as recapitalization of weak but viable banks by public funds, temporal nationalization of nonviable banks, tightening loan classification through stringent special inspections, drastic reduction of NPLs in the regulatory process, and establishing new institutions like government-funded AMCs for corporate debt restructuring, including the purchase of troubled assets. With a well-organized policy mix to solve the problems in the banking system, the NPL ratio for the major banks reduced significantly. ${ }^{16}$

Banks in Europe used both ex-ante and ex-post NPL resolution measures. ${ }^{17}$ Important ex-ante measures are strengthening bank supervision and capital requirements, structural reforms, and developing internal NPL management skills. Included in the ex-post measures was the creation of bad banks like AMCs (either public or private), whose role is to take over the impaired assets and loans. Notable among such bad banks are the full publicly owned Bank Assets Management Company of Slovenia, and the privately owned Sareb, Company for the Management of Assets Proceeding from Restructuring of the Banking System (Sareb) in Spain and the National Asset Management Agency in Ireland. Due to the diverse nature of the NPL portfolios in Europe, country-specific resolution strategies were different. Cyprus and Greece applied internal work-out approaches in resolving the NPL issue. Ireland, Slovenia, and Spain, in addition to internal work-out approaches also formed bad banks that contributed in reducing NPLs by successfully selling off assets of unviable bankrupt institutions.

12 L. Menkhoff and C. Suwanaporn. 2007. 10 Years After the Crisis: Thailand's Financial System Reform. http://diskussionspapiere.wiwi.uni-hannover.de/pdf_bib/dp356.pdf.

13 M. Xu. 2005. Resolution of Non-Performing Loans in China. 1 April 1. The Leonard N. Stern School of Business. https://pdfs.semanticscholar.org/7a5a/ e4018b7a82969a5312d5217219da40632ble.pdf.

14 A. Neagle, X. Zhang, and A. Fei. 2018. Chinese Non-Performing Loans (NPLs): SAFE enhances pilot program to facilitate purchases of NPLs by foreign investors. 12 June. King \& Wood Mallesons. https:/www.kwm.com/en/knowledge/insights/chinese-non-performing-loans-20180612.

15 Global Times. 2017. China Toughens Restrictions on Court Order Defaulters. Xinhua. 15 February. http://www.globaltimes.cn/content/1033041.shtml.

16 M. Fujii and M. Kawai. 2010. Lessons from Japan's Banking Crisis, 1991-2005. Asian Development Bank Institute Working Paper Series No. 222. June. https:// www.adb.org/sites/default/files/publication/156077/adbi-wp222.pdf.

17 D. Anastasiou. 2016. Management and Resolution Methods of Nonperforming Loans: A Review of the Literature. Munich Personal RePEc Archive Paper No. 77581. https://mpra.ub.uni-muenchen.de/77581/1/MPRA_paper_77581.pdf. 


\section{POLICY RECOMMENDATIONS AND CONCLUSIONS}

Despite several measures in Bangladesh, including the implementation of prudent measures in the banking system in 1990 and loan classification and provisioning with the international standards, the NPLs in the banking system is still very high. Bangladesh needs to explore the international best practices in NPL management and the resolution strategies implemented in other countries in Asia and the Pacific, and Europe. The management of NPLs should be multipronged, for both prevention and resolution. Some key measures are mentioned below: ${ }^{18}$

(i) To ensure that loans do not go bad and NPLs do not accumulate in the first place, corporate governance should be strengthened and careful due diligence followed in lending decisions by banks. Efforts are needed to ensure that loans are made only on commercial considerations, devoid of administrative or political influences. Similarly, effective measures are needed to ensure that sincere efforts are made at recovering loans.

(ii) Authorities should consider that SCB boards of directors be composed of competent professionals, instead of those appointed on political considerations alone. SCB management should allow full operational freedom in conducting banks' daily operations. Both the boards and management must be accountable to the central bank. The central bank should be allowed authority to ensure that individuals sitting on PCB boards possess operational knowledge of banking and finance. Changes in laws will be needed to provide required legal mandates.

(iii) The existing Bankruptcy Act, 1997, a legal framework for dealing with NPLs should be strengthened or enact a bankruptcy and insolvency law, which can be a one-stop solution consolidating all existing insolvency related laws in attaining liquidation, protecting the interests of small investors, and making the process of doing business less cumbersome. It is crucial to ensure that the revised Bankruptcy Act sets timebound procedures for Money Loan Courts to expedite the resolution of cases for settlement.

(iv) The government and the central bank should ensure rigorous enforcement of the present banking rules and regulations. The punitive measures for noncompliance of the annual performance agreement with the Ministry of Finance or the failure to meet the goals in line with the memorandums of agreement signed with the central bank should be ensured. (v) The choice of secured collaterals is important for banks to mitigate the risks associated with loans. To reduce the default risk, fair pricing of collaterals through competent accounting firms with global best practices is necessary. A data warehouse for collaterals also needs to be set up to bar borrowers from taking loans from several banks by way of using the same properties as collateral.

(vi) The government should consolidate, merge, or divest SCBs, or even privatize to bring down their number. Alternatively, SCBs can be restructured before divestment.

(vii) The government should compensate SCBs through budgetary support for their assigned social services, such as rendering financial services to underserved areas of the economy.

(viii) The authorities could also consider establishing a national AMC like the Republic of Korea's KAMCO or Malaysia's Danaharta to take over NPLs from ailing banks. After taking over NPLs and repackaging them, the AMC can sell them in the market at more realistic prices, encouraging banks to expedite the NPL resolution process. The government can take a facilitator role. The SCBs also need to be allowed to sell their NPLs to other investors. Political will backed by strong public interest in ensuring the appropriate use of public funds can facilitate AMC's success. ${ }^{19}$ The AMC could reduce imperfections in the market for stressed assets by leveraging the benefits of structured finance, thereby creating liquidity and fostering competition.

\section{REFERENCES}

Anastasiou, D. 2016. Management and Resolution Methods of Nonperforming Loans: A Review of the Literature. Munich Personal RePEc Archive Paper No. 77581. https://mpra.ub.uni-muenchen. de/77581/1/MPRA_paper_77581.pdf.

Asian Development Bank. 2019. Asian Development Outlook 2019 Strengthening Disaster Resilience. Bangladesh Chapter. April 2019. http://www.adb.org/sites/default/files/publication/492711/ ado2019.pdf.)

Bangladesh Bank. 2017. Annual Report 2016-2017. https://www. bb.org.bd/pub/annual/anreport/ar1617/index1617.php.

Bangladesh Bank. 2018. Financial Stability Report 2017. https:// www.bb.org.bd/pub/annual/fsr/final_stability_report2017.pdf.

Bangladesh Bank. Regulators of the Financial System. https://www. bb.org.bd/fnansys/regulator.php.

18 Asian Development Bank. 2019. Asian Development Outlook 2019 Strengthening Disaster Resilience. Bangladesh Chapter. April 2019. https://www.adb.org/ sites/default/files/publication/492711/ado2019.pdf.

19 H. Vora. 2017. The NPA Problem: Lessons from South Korea. Livemint. 16 August. https://www.livemint.com/Opinion/yOYcQqmanqipOLXJ6ZblOI/The-NPAproblem-Lessons-from-South-Korea.html. 
IMF. 2005. The Treatment of Nonperforming Loans (BOPCOM-05/29) - Eighteenth Meeting of the IMF Committee on Balance of Payment Statistics. Washington D.C. June 27-July 1. https://www.imf.org/external/pubs/ft/bop/2005/05-29.pdf.

Bank Negara Malaysia. 2012. Sale of Non-Performing Loans by Malaysian Banks. 20 June. http://www.bnm.gov.my/index. php?ch=en_press\&pg=en_press\&ac=80\&lang=en.

The Daily Star. 2017. Better banking for economic success. 23 February. https://www.thedailystar.net/drivers-economy/ better-banking-economic-success-1364824.

Faruk, M. O. and M. S. Islam. An Analytical Review of NonPerforming Loan: Bangladesh and Global Perspective. https://www. academia.edu/31657465/An_Analytical_Review_of_NonPerforming_Loan_Bangladesh_and_Global_Perspectives.

Fujii, M. and M. Kawai. 2010. Lessons from Japan's Banking Crisis, 1991-2005. Asian Development Bank Institute Working Paper Series No. 222. . June. https://www.adb.org/sites/default/files/ publication/156077/adbi-wp222.pdf.

Global Times. 2017. China Toughens Restrictions on Court Order Defaulters. 15 February. http://www.globaltimes.cn/ content/1033041.shtml.

International Monetary Fund. 2018. Bangladesh: Selected Issues. IMF Country Report No. 18/159. June. file://C:/Users/bkd/ Downloads/cr18159\%20(2).pdf.

Khor, M. 2005. The Malaysian Experience in Financial-Economic Crisis Management An Alternative to the IMF-Style Approach. Third World Network Global Economy Series 6. http://www.twn.my/ title2/ge/ge06.pdf.
Menkhoff, L. and C. Suwanaporn. 2007. 10 Years After the Crisis: Thailand's Financial System Reform. http://diskussionspapiere.wiwi. uni-hannover.de/pdf_bib/dp-356.pdf.

Neagle, A., X. Zhang, and A. Fei. 2018. Chinese Non-Performing Loans (NPLs): SAFE Enhances Pilot Program to Facilitate Purchases of NPLs by Foreign Investors. 12 June. King \& Wood Mallesons. https://www.kwm.com/en/knowledge/insights/chinesenon-performing-loans-20180612.

Y. C. Park. 1999. The Banking Reform in Korea: Issues and Challenges. In Bank for International Settlements. [BIS Papers No. 7: Strengthening The Banking System In China: Issues And Experience]. October. pp. 263-343. https://www.bis.org/publ/ plcy07r.pdf.

Parven, S. 2011. Nonperforming Loans of Commercial Banks in Bangladesh. Munich Personal RePEc Archive Paper No. 65248. Bangladesh Institute of Bank Management. 27 November. https:// mpra.ub.uni-muenchen.de/65248/9/MPRA_paper_65248.pdf.

Shah, S. A. H. 2008. Bangladesh Financial Sector an Agenda for Further Reforms. Asian Development Bank. https://www.adb.org/ sites/default/files/publication/27528/financial-sector-ban.pdf.

Vora, H. 2017. The NPA Problem: Lessons from South Korea. Livemint. 16 August. https://www.livemint.com/Opinion/ yOYcQqmanqipOLXJ6ZbIOI/The-NPA-problem-Lessons-fromSouth-Korea.html.

Xu, M. 2005. Resolution of Nonperforming Loans in China.

The Leonard N. Stern School of Business. 1 April.

https://pdfs.semanticscholar.org/7a5a/

e4018b7a82969a5312d5217219da40632b1e.pdf.

The views expressed in this publication are those of the authors and do not necessarily reflect the views and policies of ADB or its Board of Governors or the governments they represent. ADB encourages printing or copying information exclusively for personal and noncommercial use with proper acknowledgment of ADB. Users are restricted from reselling, redistributing, or creating derivative works for commercial purposes without the express, written consent of ADB.

Asian Development Bank

6 ADB Avenue, Mandaluyong City

1550 Metro Manila, Philippines

Tel +63286324444

Fax +63286362444

www.adb.org/publications/series/adb-briefs

ADB recognizes "China" as the People's Republic of China and "Korea" or "South Korea" as the Republic of Korea. 